- $10-29180$

NASA Technical Memorandum 88848

IAF-86-183

\title{
Status of Advanced Propulsion for Space Based Orbital Transfer Vehicle
}

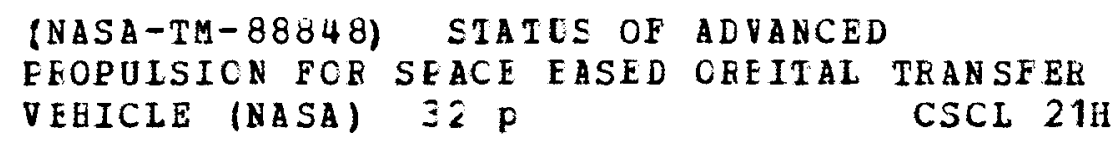

Larry P. Cooper and Dean D. Scheer

Lewis Research Center

Cleveland, Ohio

Prepared for the 37th Congress of the International Astronautical Federation Innsbruck, Austria, October 4-11, 1986 


\title{
STATUS OF ADVANCED PROPULSION FOR SPACE
}

\section{BASED ORBITAL TRANSFER VEHICLE}

\author{
Larry P. Cooper and Dean D. Scheer \\ National Aeronautics and Space Administration \\ Lewis Research Center \\ Cleveland, Ohio 44135
}

\begin{abstract}
SUMMARY
A new Orbital Transfer Vehicle (OTV) propulsion system will be required to meet the needs of space missions beyond the mid-1990's. As envisioned, the advanced OTV will be used in conjunction with earth-to-orbit vehicles, Space Station, and Orbit Maneuvering Vehicle. The OTV will transfer men, large space structures, and conventional payloads between low earth and higher energy orbits. Space probes carried by the OTV will continue the exploration of the solar system. When lunar bases are established, the OTV will be their transportation link to earth.
\end{abstract}

NASA is currently funding the development of technology for advanced propulsion concepts for future Orbital Transfer Vehicles. Progress in key areas during 1986 is presented.

\section{INTRODUCTION}

As expressed in "The Report of the National Commission on Space" (ref. 1) we may well see the pioneering of the space rrontier over the next fifty years. One of the major space transportation system requirements established by the Commission was round trip transfer beyond low earth orbit utilizing an orbital Transfer Vehicle.

As shown in figure 1, the Orbital Transfer Vehicle (OTV) is a key element of the envisioned space infrastructure of the 1990's and beyond. Other elements include the Space Station, Orbit Maneuvering Vehicle, and a variety of earth-to-orbit vehicles. In this scenario, the orbital Transfer vehicle would be reusable and operate primarily between low earth orbit and geosynchronous orbit. The majority of its missions would be for delivery of satellites and manned servicing in geosynchronous orbit. In addition, it would serve as the transportation mode between the earth and moon and would place planetary probes on their transfer trajectories.

To prepare for the needs of future Orbital Transfer Vehicles, NASA in 1981 initiated an Advanced OTV Propulsion Technology Program. The objective of this program is to establish by the early 1990's, the technology base for a high performance, multiple restart, variable thrust, orbital transfer propulsion system which could be man-rated, space or ground based, and compatible with aeroassist maneuver concepts. This paper reviews ongoing NASA sponsored efforts to advance OTV propulsion technology. 
The Advanced OTV Propulsion Technology Program is currently pursuing key technologies for three concepts for advanced OTV engines. These concepts and key technologies were defined in studies completed in 1983 and subsequently updated in 1986 by Aerojet General. Aerojet Techsystems Company: Rockwell Internationa1, Rocketdyne Division; and United Technologies, Pratt \& Whitney. These engines reflect the Program requirements as shown in Table I. The propellants are limited to cryogenic hydrogen-oxygen and total vehicle vacuum thrust level is between 10000 to 25000 lb with multiple engines. In addition to these specific requirements, several goals have been established reflecting desirable characteristics for an advanced engine. These goals are listed in table II. In total, they represent a set of highly ambitious characteristics, and were established as technical challenges to generate options and tradeoffs, since all goals may not be achievable singularly or concurrently. The rationale which led to the specific numerical requirements and goals are discussed in reference 2 .

The three engine concepts are summarized below with changes from the 1983 configurations noted.

\section{Aerojet Techsysterns Company}

A 3000 ib thrust propellant expander cycle engine was selected in 1983 (ref. 3). The thrust level of the updated engine has been increased from $3000 \mathrm{lb}$ to $7500 \mathrm{lb}$ to reflect the general preference for dual engine configurations (refs. 4 to 6) rather than the six engine concept proposed earlier. The engine's specific impuise is predicted to be in excess of $480 \mathrm{~s}$ at a mixture ratio of 6.0 and is obtained through utilizing a chamber pressure of 2000 psia and a nozzle area ratio of 1000:1. The fixed nozzle has been replaced by an extendible portion and the area ratio has been reduced from 1200:1 to maintain overall engine length at 60 in. in the retracted position.

The flow schematic of the Aerojet concept is shown in figure 2 . The key feature of the dual propellant expander cycle is that both hydrogen and oxygen are used to drive their respective turbopumps. This approach enables a higher chamber pressure to be obtained than with the conventional hydrogen expander for this engine thrust size. It also eliminates interpropellant seals in the oxidizer turbopump and could eliminate inert gas on the OTV to purge interpropellant seals.

The critical technology issues identified for this engine concept are the hazard of explosion or combustion of oxygen turbine materials exposed to the warm gaseous oxygen and the dual propellant cooled annular thrust chamber.

\section{Rocketdyrie}

A 15000 lb thrust hydrogen expander cycle with hydrogen regeneration was baselined in 1983 ( $r$ ef. 7 ). The concept has been resized from 15000 ib to $7500 \mathrm{lb}$ thrust to accommodate the preferred dual engine configurations. At a mixture ratio of 6.0 , the concept has a predicted specific impulse in excess of $480 \mathrm{~s}$ with a chamber pressure of $1831 \mathrm{psia}$ and an extendible nozzle of 1080 area ratio. The nozzle has been reduced to a single extendible section to 
reduce complexity and the area ratio has been reduced to maintain the overall engine length below 120 in. when the nozzle is deployed.

The propellant flow schematic for this expander cycle is shown in figure 3. Key features identified as technology issues are chamber heat extraction and life enhancements for longitudinal ribs on the hot-gas side and fins in the coolant channels and advanced turbomachinery concepts such as a twostage partial admission turbine and soft wear ring seals.

\section{Pratt \& Whitney}

The 1983 Pratt \& Whitney baseline was a hydrogen expander cycle with hydrogen regeneration at a thrust level of 15000 lb (ref. 8). This concept has also been resized from $15000 \mathrm{lb}$ to $7500 \mathrm{lb}$ to accommodate the preferred dual engine configurations. At a mixture ratio of 6.0 , predicted specific impulse is slightly less than $480 \mathrm{~s}$ with a chamber pressure of 1210 psia and a single section extendible nozzle of 600 area ratio.

The propellant flow schematic for the Pratt \& Whitney concept is shown in figure 4. A unique feature of this concept is the hydrogen cooled gear train in the turbopump assembly which synchronizes the main oxygen and fuel pumps and drives the low speed boost pumps. Key technology issues in this concept are heat extraction capability and life of the thrust chamber and life of the hydrogen cooled gear train.

\section{TECHNOLOGY PROGRAMS}

Based upon the engine concepts and identified technology needs, a comprehensive effort was begun in 1983 to demonstrate technology readiness of each concept for a Design, Development, Test, and Engineering (DOT\&E) program in the early 1990 's. Highlights of 1986 advancements in key technology areas are summarized below.

\section{Turbomachinery Technology}

Partial admission turbine. The Rocketdyne design incorporates a twostage partial admission turbine in the fuel turbopump. A series of tests and analyses have been completed to verify the analytical design predictions, update the prediction methodologies, and provide a baseline data set for comparison with future enhancements of the turbine. The tests were conducted in nitrogen and included variations in the degree of turbine admission and nozzle angulation on performance. Results of these tests are shown in figures 5 and 6 . Performance of the turbine at the design condition (highest admission fractions and a velocity ratio of 0.286 ) was approximately 11 percent higher than originally predicted. This is most likely a result of windage losses being lower than expected. Effects and trends of nozzle arc of admission variation were generally as expected with the lowest performance coincident with the lowest arc of admission. In addition, large deviations from the design point nozzle-tonozzle angulation setting produced the lowest performance.

Soft wear ring seals. - In order to maintain high turbopump performance with iong operational life, Rocketdyne is considering the use of turbopump 
seals manufactured from plastic materials. These seals would permit tighter clearances with significantly reduced risks due to rubs. Polyurethane materials are candidates for liquid hydrogen service and poiyimides for liquid oxygen and warm gaseous hydrogen. Initial screening of materials for oxygen service has been completed. The screening consisted of impact, autoignition, and promoted ignition tests in oxygen. Shown in figure 7 are burn rate results as determined from the promoted ignition tests. Data from these tests have been incorporated into a model of seal rub energy dissipation within the rotor to stator system. This model provides a ranking of seal materials based upon the turbopump environmental factors and upon the material characteristics of the seals, rotor, and stator. Evaluation of the seal materials is now underway in a friction rubbing tester, figure 8 . Rubbing velocities up to $150 \mathrm{fps}$, loads to $25 \mathrm{ps} i$ and oxygen pressures to 300 psi can be obtained.

0xygen turbopump bearings. - Bearing life in existing reusable rocket engines have fallen far short of the goals for OTV engine program. Aerojet has incorporated hydrostatic bearings into their concepts of fuel and oxidizer turbopumps. These bearings have been shown in laboratory tests to have virtually unlimited life when metal on metal contact is eliminated. The critical oxygen turbopump bearings are being evaluated in a bearing tester which closely resembles the turbopump. Components of the tester are shown in figure 9 prior to assembly. Figure 10 is a cross-sectional view of the tester. Initial tests in nitrogen are in progress to demonstrate rotor support system integrity, and provide data for verification/update of analysis methods. Subsequent tests involving fluid changes from nitrogen to oxygen and component changes which evolve the tester into a turbopump for performance testing are planned for late 1986.

Oxygen compatible turbopump materials. - The Aerojet engine concept utilizes a gaseous oxygen driven turbine for the oxygen pump. Experience has shown that rubs in high pressure gaseous oxygen can result in catastrophic failure of the turbopump. Some materials are more prone to ignition than others. A ranking methodology based on the material burn factor has been previously validated in this program (ref. 9). Those results were for the rubbing of identical materials. Extension of these results to rubbing of dissimilar metals has now been completed. It was originally postulated that rubbing a material with a low burn factor against one with a higher burn factor could significantly increase the temperature for ignition. The lower burn factor material would be an improved heat sink for the rub energy as compared to rubbing identical materials. The results of the dissimilar metals evaluation are tabulated in table III. In general, it has been found that the ignition characteristics of dissimilar materials are dominated by the most ignitable of the materials. Additional heat sink capacity is apparently unable to remove energy rapidly enough to prevent ignition initiation in the more susceptible material. Introduction of highly burn resistant metals as one of the rubbing surfaces appears of little value in preventing ignition.

\section{Combustion Devices Technology}

Combustion chamber ribs. - The expander cycle derives its turbopump drive energy from heat extracted from the chamber and nozzle. Maximizing the energy extracted provides for the highest chamber pressures and smallest engine envelop for a given expansion ratio. One method to increase energy extraction is to provide ribs on the hot gas side of the chamber to increase the avallable surface area and enhance the heat transfer coefficient over the smooth wall 
condition. Evaluation of this concept with hot air tests was completed by Rocketdyne (ref. 10). Extension of the test results to hot fire conditions has now been analyticaliy assessed. The hot air data were extrapolated by incorporating corrections for density, velocity, heat capacity, and compressibility. As shown in figure 11, enhancement of over 40 percent in energy extraction is anticipated for the best configuration. Fabrication of a ribbed calorimeter chamber is now in progress. Testing to validate the hot fire projections is expected to begin in 1987.

Coolant channel enhancement. - Low cycle fatigue of the thrust chamber is one of several life limiting phenomena in rocket engines. Chamber life can be increased by reducing the chamber wall temperature. However, this must be done without reducing the total amount of energy extracted in order to maintain the expander cycle performance level. Enhancing the coolant passage heat transfer has been proposed by Rocketdyne. Candidate channel geometries have been evaluated based on structural durability, coolant pressure drop, producibility, and heat load enhancement. Several scale model configurations were air flow tested by Rocketdyne as shown in figure 12. Results of these tests are shown in figure 13, scaled for hydrogen at the proper conditions at the end of the combustor cylindrical section. As compared to the reference rectangular channel, the channel with a single high fin reduced the wall temperature by approximately $40^{\circ} \mathrm{F}$ at the design hot fire condition. Calorimeter chambers with enhanced coolant passages are being fabricated and are to be tested in 1987. The final step will be to combine the rib and fin configuration into a thrust chamber for testing in 1988 .

Annular thrust chamber. - The Aerojet $01 \mathrm{~V}$ engine concept utilizes a cylindrical centerbody in the thrust chamber to increase the overall surface area for energy extraction. Initial evaluation of this annular thrust chamber concept has been completed with heat sink hardware. A cross-sectional view of the heat sink chamber and injector is shown in figure 14. Chamber components are shown in figure 15. Thirty-five hot-fire tests were conducted to verify the stability, throttleability, performance, and heat transfer characteristics of the thrust chamber assembly. The chamber pressures ranged from idle mode conditions (30-35 psia) to 600 psia while mixture ratio was varied from 3 to 9 . The chamber was instrumented to obtain axial heat flux profile along the chamber length. Typical results as shown in figure 16 reveal acceptable levels of heat flux. The chamber performance exceeded 95 percent energy release efficiency at low pressure operation and approached 100 percent as the chamber pressure was increased. The chamber was stable at all test conditions. High frequency pressure measurements revealed no oscillations. Post test inspection showed no abnormal discoloration or streaking. Preparations are now underway to extend test conditions to 2400 psia. A hydrogen cooled throat insert has been completed and will replace the heat sink throat. These tests are expected to begin in late 1986.

Long life chamber materials. - The copper alloy used in the Space Shuttle Main Engine thrust chamber has shown a tendency to undergo surface roughening in operation. This leads to undesirable heat transfer conditions and premature failure through wall cracking. Since the $01 \mathrm{~V}$ engine may require space based inspection and maintenance, methods to avoid these material related failures is desirable.

One potential method to produce copper alloys with better Low Cycle Fatigue performance is rapid solidification rate powder metallurgy. Using this 
process, materials are produced with supersaturated concentrations of desirable agents for enhanced ductility, strength, and microstructure phase stability. Copper alloy systems with Chromium, Zirconium, Hafnium, Silver, and with dispersed metal borides and silicides have been investigated by Pratt \& Whitney. Several pounds of alloys have been produced by atomization, then consolidated, processed, and tested for alloy characteristics. Most copper alloys exhibit improved mechanical properties and thermal stability.

Low cycle fatigue results are shown in figure 17 for a typical copperhafnium alloy as compared to an alloy with composition similar to the alloy used in the Space Shuttle Main Engine thrust chamber.

\section{Close Coupled Component Technology}

Integrated component evaluation. - Complete assessment of the various subcomponent and component technologies will require evaluation under realistic operating conditions simulating the closely coupled nature of the expander cycle engine. Rocketdyne has provided a baseline system consisting of a thrust chamber and turbopump feed system as shown in figure 18. Advanced technology features will be incorporated into the system for characterization. Tests to establish the baseline turbopump data set have been successfully completed with an accumulated run time of $380 \mathrm{sec}$ at pumped idle and moderate power level conditions. Hot fire tests have been initiated and have thus far achieved chamber operating pressures of 700 psia.

Integrated control and health monitoring (ICHM). - Satisfactory completion of the multiple burn OTV missions and the effective maintenance of the engine in space will likely require an advanced ICHM system. It will need to monitor the engine's health during operation and idle periods, detect imminent failures, provide warnings for maintenance needs, and provide adaptive control action to delay failure until maintenance can be effected.

Aerojet and Rocketdyne have completed conceptualization of their ICHM systems. The Aerojet approach is shown in figure 19. It consists of a four level hierarchy. At the top are those features required for control of the engine operation. The second layer is dedicated to detection of major anomalies which require immediate engine shutdown. Next are the functions related to detection of anomalies whose effects can be relieved by operation at alter. native engine conditions, such as reduced thrust or mixture ratio. The final level consists of functions related to trend monitoring, analysis, and recording. This level provides guidance for between flight and maintenance needs. Evaluation of engine fallure modes has also been completed. Shown in table IV are the modes, sensors, and corrective actions identified for the Rocketdyne turbopump concept.

Space operable disconnects. - A key element of the reusable oTV engine is the concept of space maintenance. It is posiible that some element of the engine will deteriorate or fall prior to reaching the engine life goal. Replacement of the engine or its components would then be needed. Space operable disconnects are required to permit coupling and decoupling on orbit by astronauts in space suits and/or robotic servicing devices. They must be easy to use, highly reliable, and not contribute significant weight or envelop penalties. 
Disconnects can be grouped by interface type into propellant, pneumatic, structural, power, and data. Attention has been focused on propellant interface joints and a number of concepts have been identified.

A Rocketdyne engine change-out disconnect design concept is shown in figure 20. This carriage-hook concept features a simple fixed coupling half with the entire mechanism contained on the removable half. A rotating drive sleeve (which may be either manually actuated or powered) causes a carriage to axially translate for or aft. Splines prevent rotation of the carriage. Hooks are mounted to the carriage with springs to normally hold them in the assembled, or closed, position. As shown in the upper view, the hooks are forced to rotate clear of the fixed flange as the coupling begins to connect. When the fixed flange nears seating, the hooks are free to snap back against their stops. Actuation of the drive sleeve causes the carriage to translate until the hooks contact and load the back of the fixed flange. Proper loading of the joint can be determined by torquing the drive sleeve or by measuring the strain on each of the easily accessible tension legs of the carriage.

\section{CONCLUDING REMARKS}

Although a development decision for the OTV has not yet been made, the need for an advanced OTV is acknowledged if we are to fulfill the vision of pioneering the space frontier. NASA has an ongoing effort for OTV propulsion technology. It is pointed towards enabling a low risk, minimum cost design, development, test, and engineering (DDT\&E) program for an advanced engine in the early 1990's. Analytical and experimental efforts will continue at the subcomponent level in 1987. Component testing will begin in 1988 under current plans.

\section{REFERENCES}

1. Pioneering the Space Frontier. Bantam Books, 1986.

2. Cooper, L. P.: Advanced Propulsion Concepts for Orbital Transfer Vehicles. AIAA Paper 83-1243, June 1983.

3. Schoenman, L.: Orbit Transfer Rocket Engine Technology Program. NASA CR-168157, 1983.

4. Orbital Transfer Vehicles: Concept Definition and Analysis Study, Phase II, Final Review. GDSS-SP-86-011, General Dynamics Space Systems, 1986.

5. Orbital Transfer Vehicles: Concept Definition and Analysis Study, Phase II, Final Review. Martin Marietta, 1986.

6. Orbital Transfer Vehicles: Concept Definition and Analysis Study, Phase II, Final Review. Boeing Aerospace, 1986.

7. Martinez, A.: Orbit Transfer Rocket Engine Technology Program. Volume I Study Results. (RI/RD-83-131-2-VOL-1, Rockwe11 International; NASA Contract NA53-23172). NASA CR-168158; Volume II - Supplemental Data. (RI/RD-83-1313-Vol-2, Rockwell International; NASA Contract NA53-23172). NASA CR-168316, 1984 . 
8. Orbit Transfer Rocket Engine Technology Program. NASA CR-168156, 1984.

9. Schoenman, L.: Selection of Burn-Resistant Materials for Oxygen-Orive Turbopumps. AIAA Paper 84-1287, June 1984.

10. Bally, R.D., Defever, G.J., and Wagner, W.R.: Enhanced Heat Transfer Rocket Combustor Technology. 1985 JANNAF Propulsion Meeting, CPIA-PUB-425, Vo1. 4, Chemical Propulsion Information Agency, 1985, pp. 251-259. 
TABLE I. - REQUIRED ADVANCED OTV PROPULSION SYSTEM CHARACTERISTICS

\begin{tabular}{|c|c|}
\hline Characteristic & Requirement \\
\hline $\begin{array}{l}\text { Propellants - fuel } \\
\text { oxidizer } \\
\text { Vacuum thrust (design point range), lbfa } \\
\text { Engine mixture ratio, } 0 / F \text { (design point) } \\
\text { Engine mixture ratio range, } 0 / F \\
\text { Propellant inlet temperature, }{ }^{\circ} \mathrm{R} \text { - hydrogen } \\
\text { oxygen } \\
\text { Thrust vector control, degree } \\
\text { Start cycle }\end{array}$ & \begin{tabular}{|l}
$\begin{array}{r}\text { Hydrogen } \\
\text { Oxygen }\end{array}$ \\
10000 to 25000 \\
6.0 \\
5.0 to 7.0 \\
37.8 \\
162.7 \\
\pm 6.0 \\
Chilldown with propulsive \\
dumping of propellants, \\
engine start with pump inlets \\
at propellent tank vapor \\
pressure.
\end{tabular} \\
\hline
\end{tabular}

avacuum thrust range may be obtalned from either a single engine or multiple engine configurations having total thrust within the specifted range.

TABLE II. - ADVANCED OTV PROPULSION SYSTEM GOALS

\begin{tabular}{|l|r|}
\hline \multicolumn{1}{|c|}{ Characteristic } & \multicolumn{1}{|c|}{ Goal } \\
\hline Vacuum specific impulse, lbf-sec/lbm & 520 \\
Vacuum thrust throttle ratio & $30: 1$ \\
Net positive suction head, ft-lbf/lbm & \\
Hydrogen & 0 \\
Oxygen & 0 \\
Weight, lbm & 360 \\
Length (stowed), in. & 40 \\
Reliability & 1.0 \\
Service life & $500 / 20$ \\
Between overhauls, cycles/hours & $100 / 4$ \\
Service free, cycles/hours & \\
\hline
\end{tabular}


TABLE III. - IGNITION SENSITIVITY OF FRICTION RUBBING MATERIALS

IN OXYGEN

\begin{tabular}{|l|c|l|c|c|}
\hline Sample & $\begin{array}{c}\text { Burn } \\
\text { factor }\end{array}$ & \multicolumn{1}{|c|}{ Sample } & $\begin{array}{c}\text { Burn } \\
\text { factor }\end{array}$ & $\begin{array}{c}\text { Temperature } \\
\text { at Ignition }\end{array}$ \\
\hline Zirconfum Copper & 35 & Z1rconfum Copper & 35 & $>1800 a$ \\
Monel K500 & 2090 & Monel K500 & 2090 & 1875 \\
316 Stainless Steel & 4515 & 316 Stainless Steel & 4515 & 750 \\
316 Stainless Steel & 4515 & Monel K500 & 2090 & 640 \\
316 Stainless Steel & 4515 & Zirconium Copper & 35 & 580 \\
\hline
\end{tabular}

aNo ignition test 11 mited by sample deformation.

TABLE IV. - TURBOPUMP FAILURE MODES ANO RELATEO SENSORS

\begin{tabular}{|c|c|c|c|}
\hline Fallure mode & Measurand & Sensor & $\begin{array}{l}\text { Corrective action } \\
\text { during operation }\end{array}$ \\
\hline Bearing wear/failure & $\begin{array}{l}\text { Material depletion } \\
\text { Deformation } \\
\text { Deformation } \\
\text { Appearancea }\end{array}$ & $\begin{array}{l}\text { Is otope detector } \\
\text { Deflectometer } \\
\text { Eddy current } \\
\text { indicator } \\
\text { Fiber optic } \\
\text { orobe }\end{array}$ & $\begin{array}{l}\text { Reduce speed } \\
\text { Reduce speed } \\
\text { Reduce speed }\end{array}$ \\
\hline & $\begin{array}{l}\text { Vibration } \\
\text { Vibration }\end{array}$ & $\begin{array}{l}\text { Accelerometer } \\
\text { Laser vibrometer }\end{array}$ & $\begin{array}{l}\text { Reduce speed } \\
\text { Reduce speed }\end{array}$ \\
\hline Shaft seal wear/failure & $\begin{array}{l}\text { Material depletion } \\
\text { Cavity press } \\
\text { Seal appearance }\end{array}$ & $\begin{array}{l}\text { Isotope } \\
\text { Pressure } \\
\text { transducer } \\
\text { Fiber optic } \\
\text { probe }\end{array}$ & $\begin{array}{l}\text { Shutdown } \\
\text { Shutdown }\end{array}$ \\
\hline Turbine blade cracks & Blade appearancea & $\begin{array}{l}\text { Fiber optic } \\
\text { probe }\end{array}$ & \\
\hline Turbine blade fatigue & $\begin{array}{l}\text { Blade conditiona } \\
\text { Electron fluxa }\end{array}$ & $\begin{array}{l}\text { Acousto-optics } \\
\text { Exoelectron } \\
\text { emission }\end{array}$ & \\
\hline Seal/bearing binding & Shaft torque & $\begin{array}{l}\text { Ferromagnetic } \\
\text { torquemeter }\end{array}$ & Shutdown \\
\hline$T / P$ overspeed & Shaft speed & $\begin{array}{r}\text { Ferromagnetic } \\
\text { torquemeter }\end{array}$ & Reduce speed \\
\hline Pump cavitation & Inlet pressure & $\begin{array}{l}\text { Pressure } \\
\text { transducer }\end{array}$ & Reduce speed \\
\hline
\end{tabular}

aretween tests. 


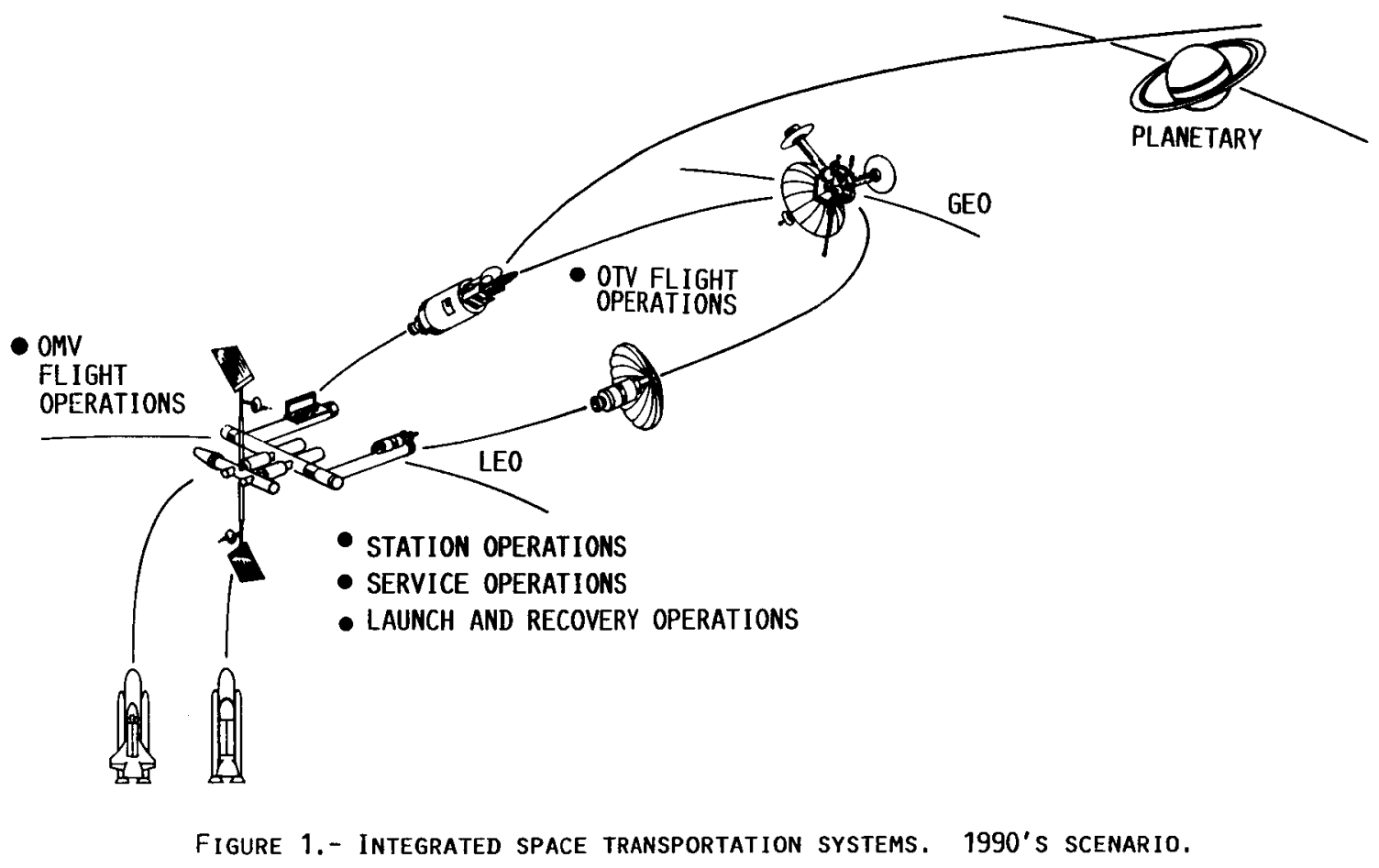




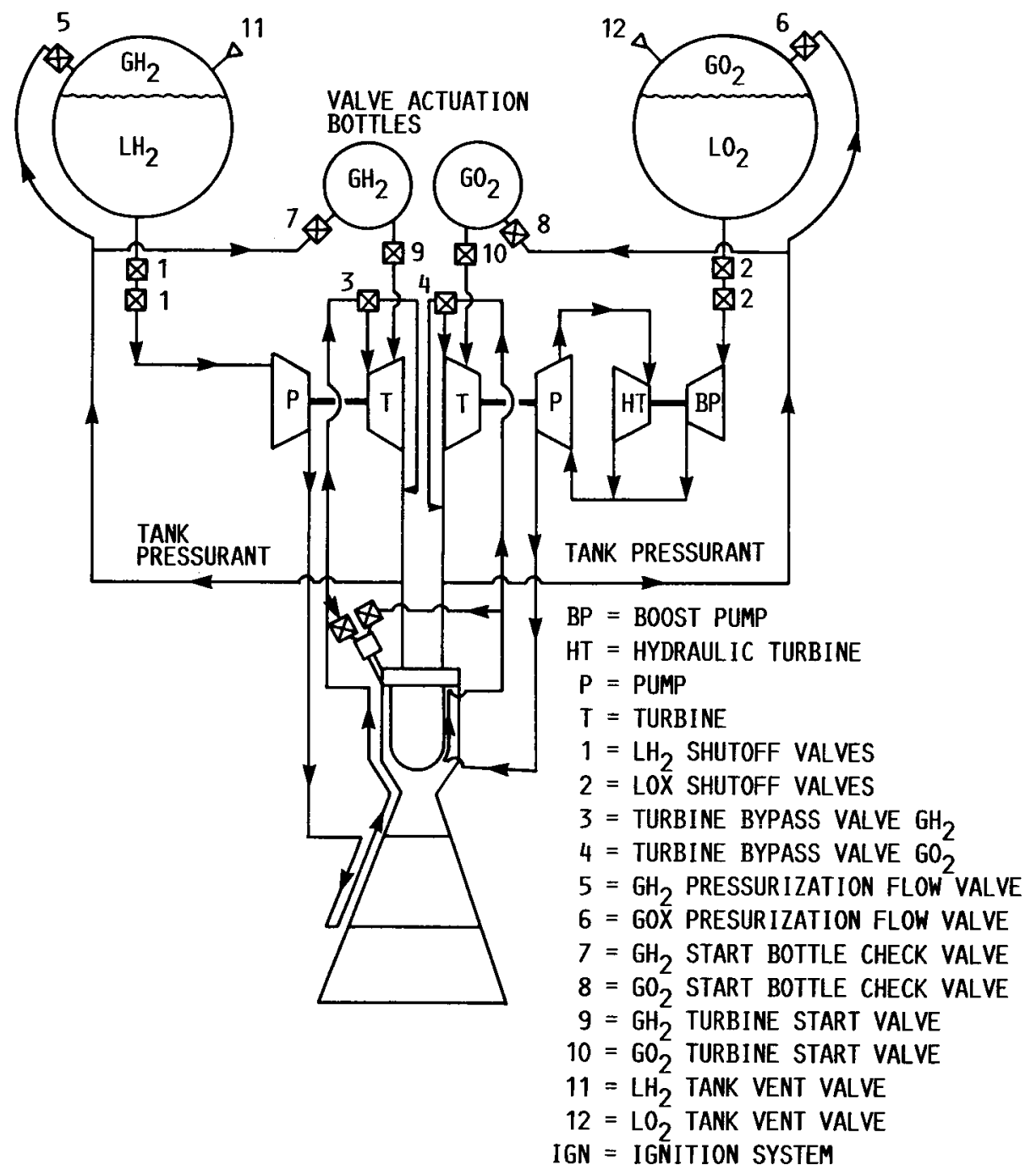

Figure 2. - Flow SCHEMATIC; AEROJET ADVANCED OTV PROPULSION CONCEPT. 
ENGINE CONTROLS

(1) IFV = INLET FUEL VALVE

(2) IOV = INLET OXIDIZER VALVE

(3) MFV = MAIN FUEL VALVE

(4) MOV = MAIN OXIDIZER VALVE

(5) TBV = TURBINE BYPASS VALVE

(6) OTBV = OXIDIZER TURBINE BYPASS VALVE

(7) GOV = GASOUS OXIDIZER VALVE

(8) DFV = DUMP FUEL VALVE

(A) FUEL FLOW HYDRAULIC TURBINE

FOR LOW PRESSURE LOX PUMP

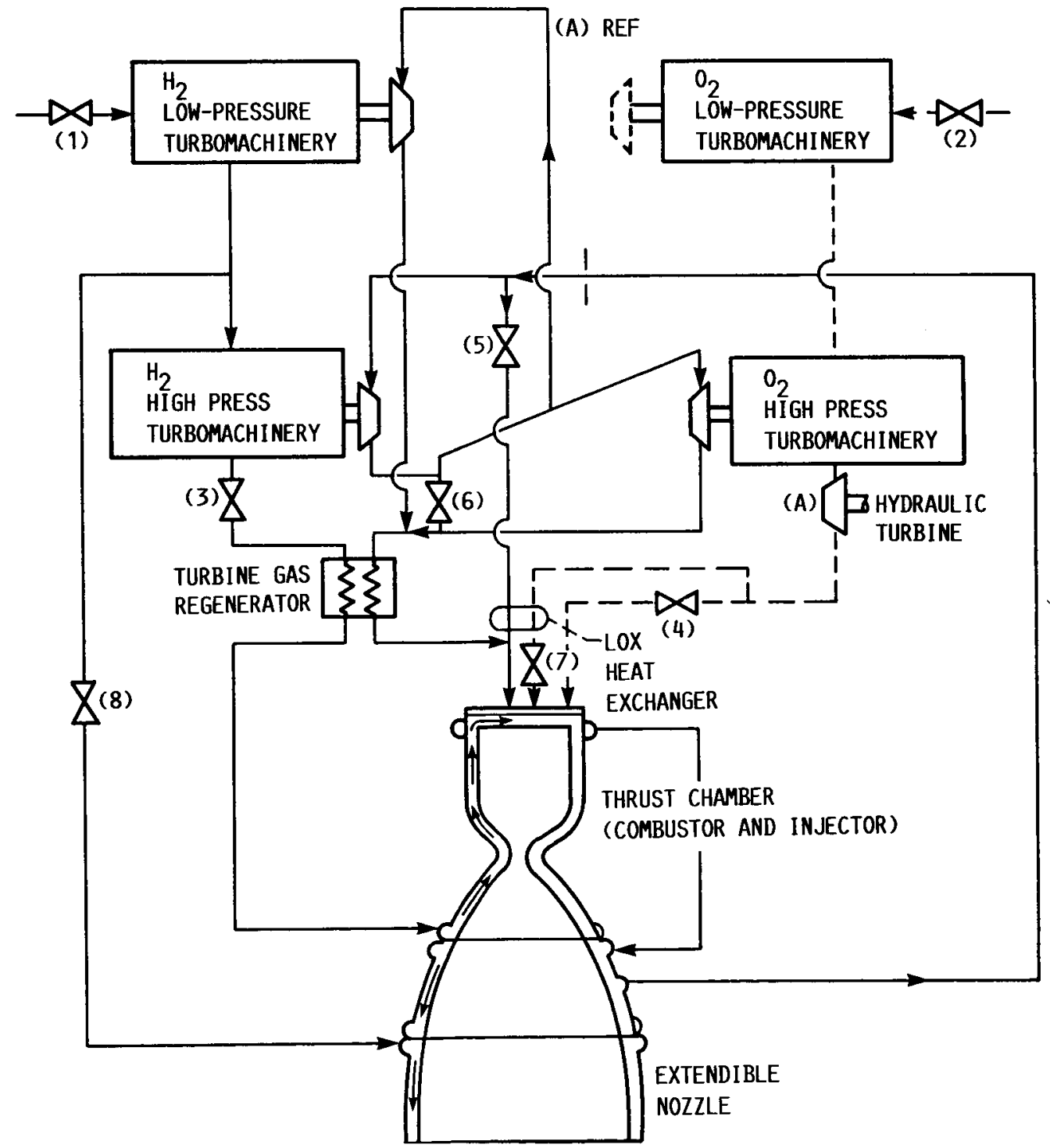

Figure 3.- Flow SCHEMATIC: ROCKETDYNe AdVANCED OTV PROPUlsion CONCEPT. 


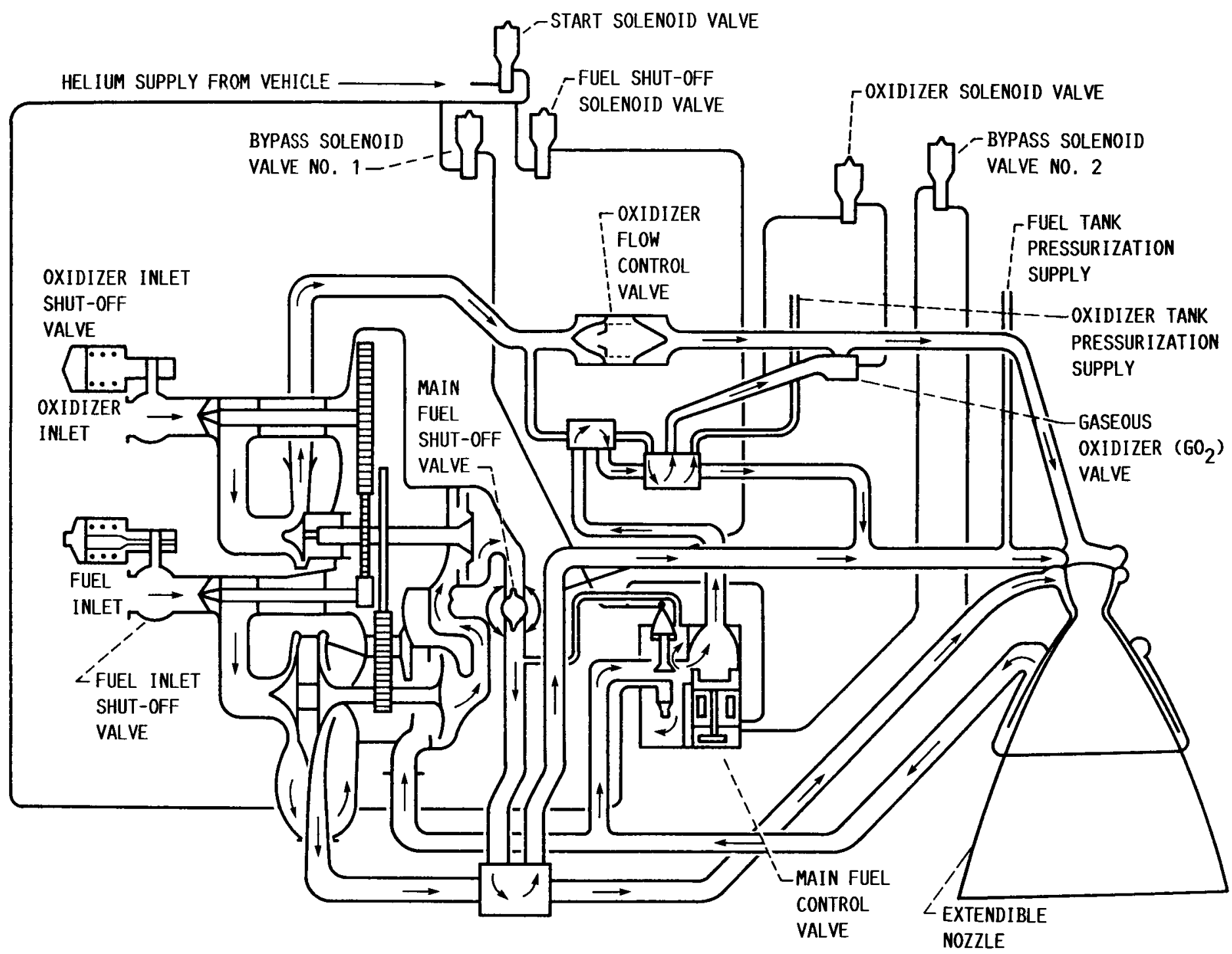

Figure 4.- Flow schematic: Pratt \& Whitney advanced OTV propulsion concept. 


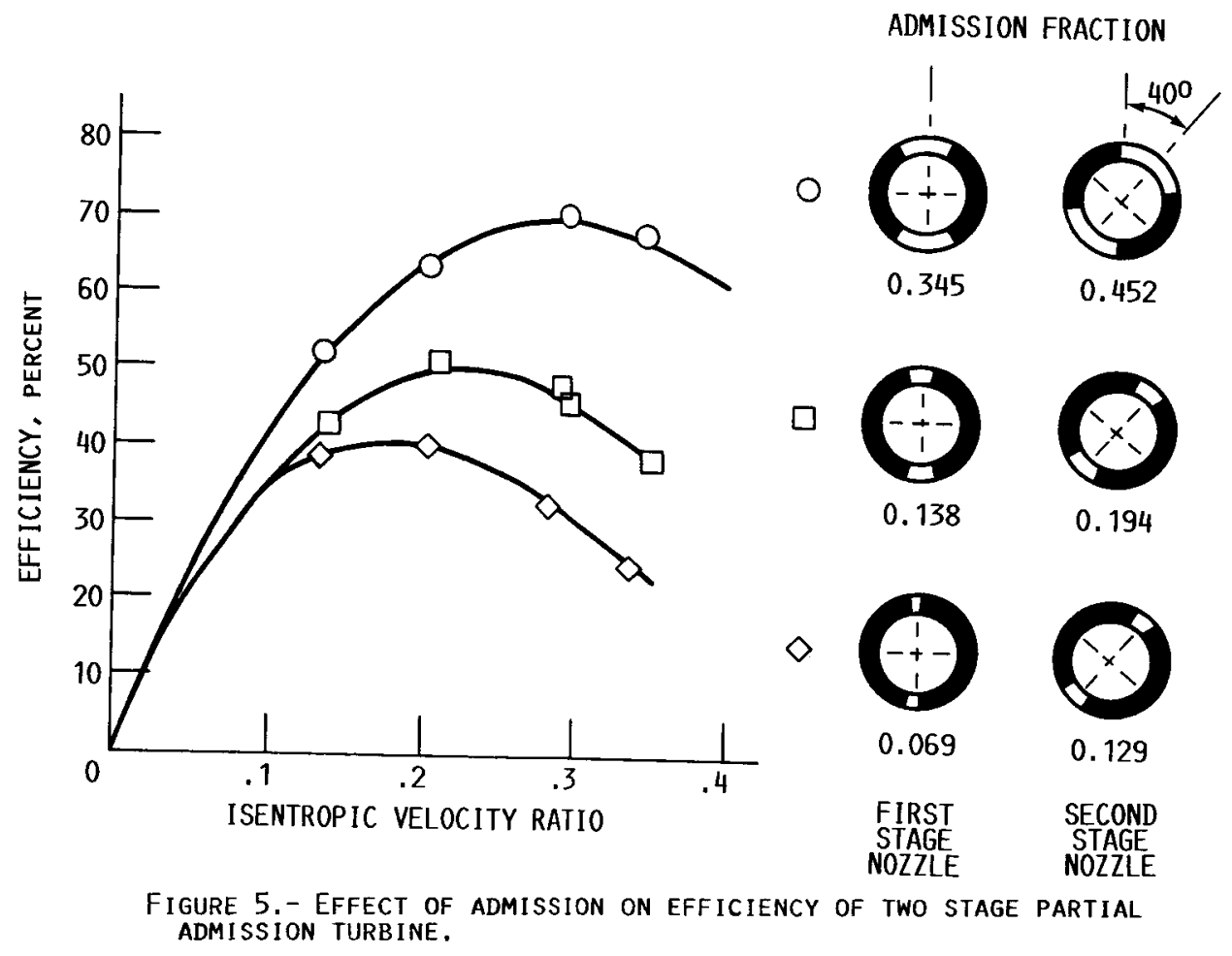




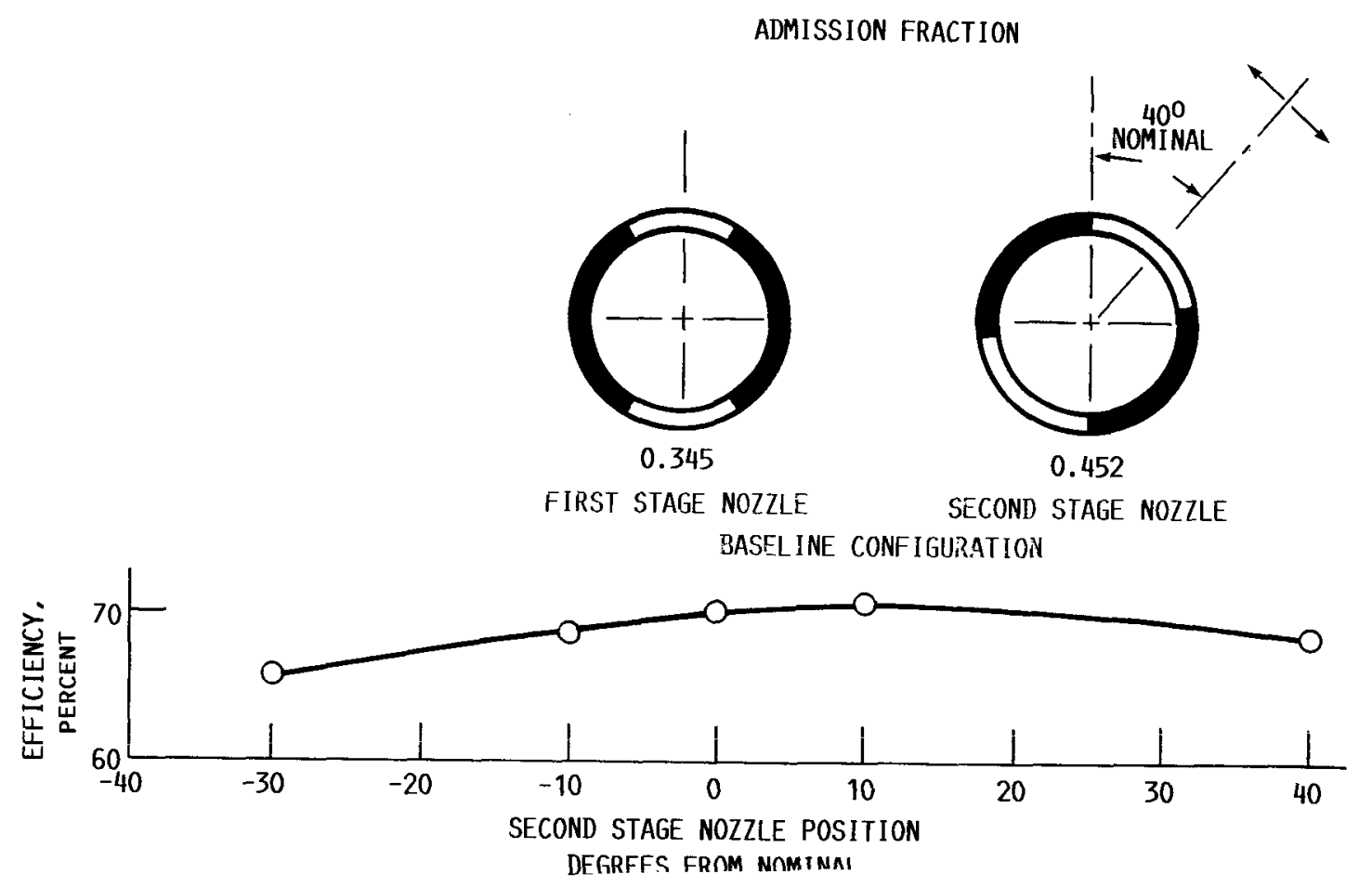

FiguRE 6.- EFFECT OF NOZZLE ORIENTATION ON EFFICIENCY OF TWO STAGE PARTIAL ADMISSION TURB INE. 


$$
\text { 望圈圆 }
$$




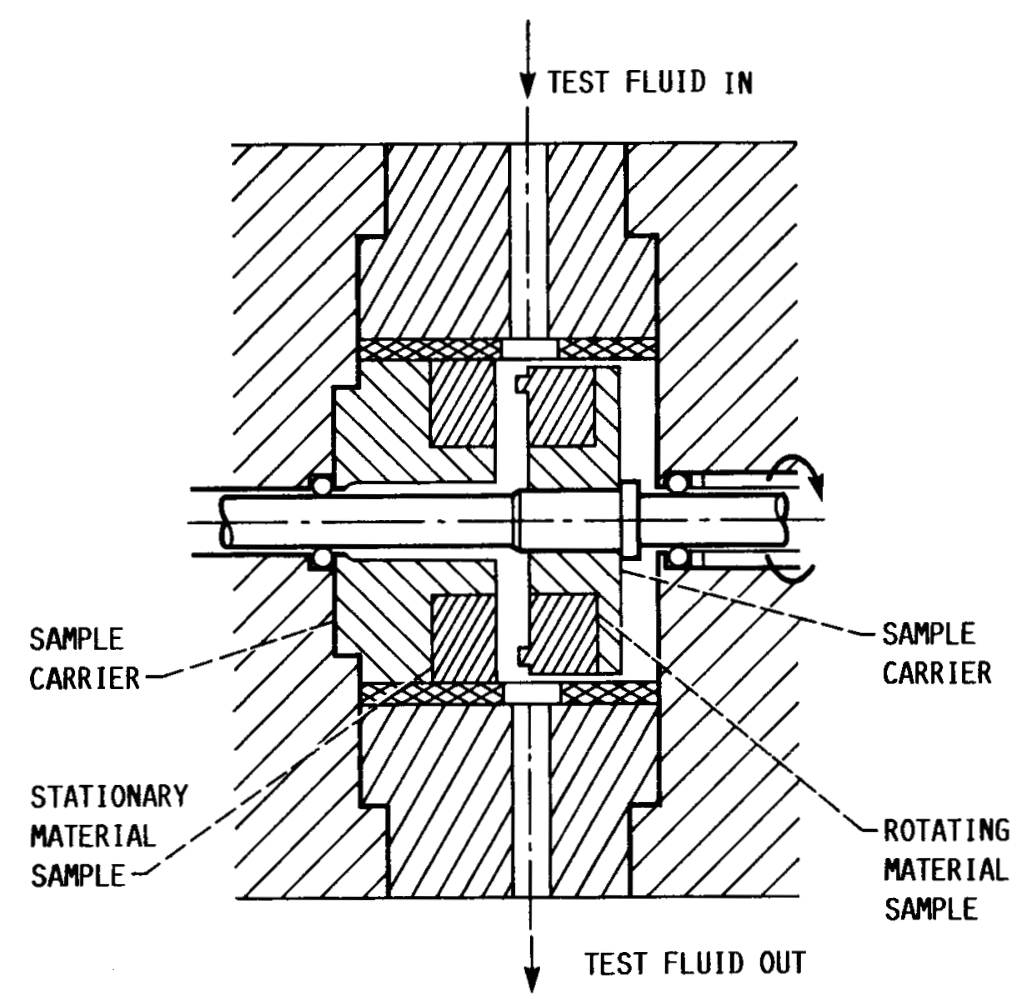

FIGURE 8. - SOFT WEAR RING SEAL FRICTION AND WEAR TESTER. 


\section{ORTGINAL PAGE \\ OF POOR OUALTY}

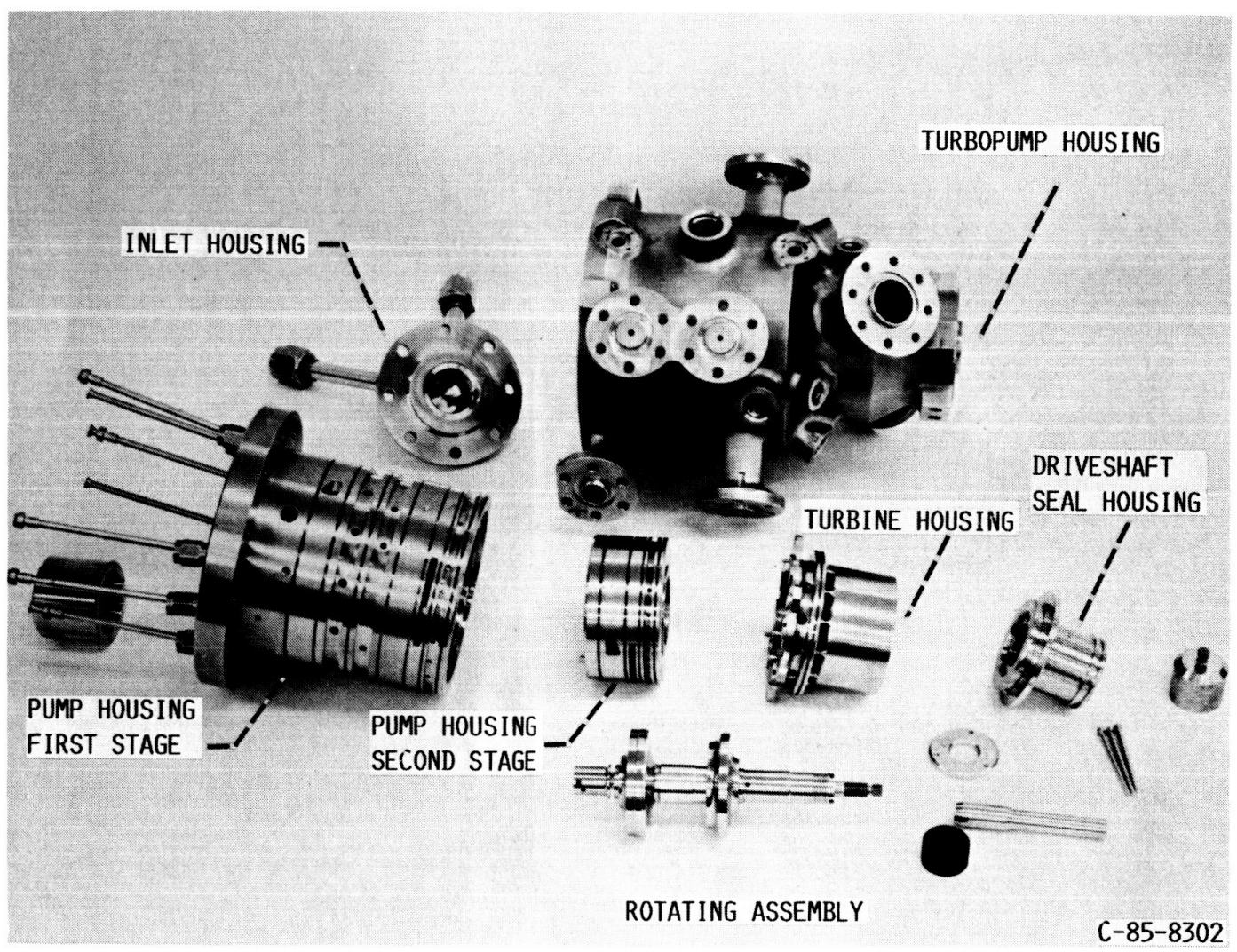

Figure 9. - HydRostatic BEARINg tester components. 


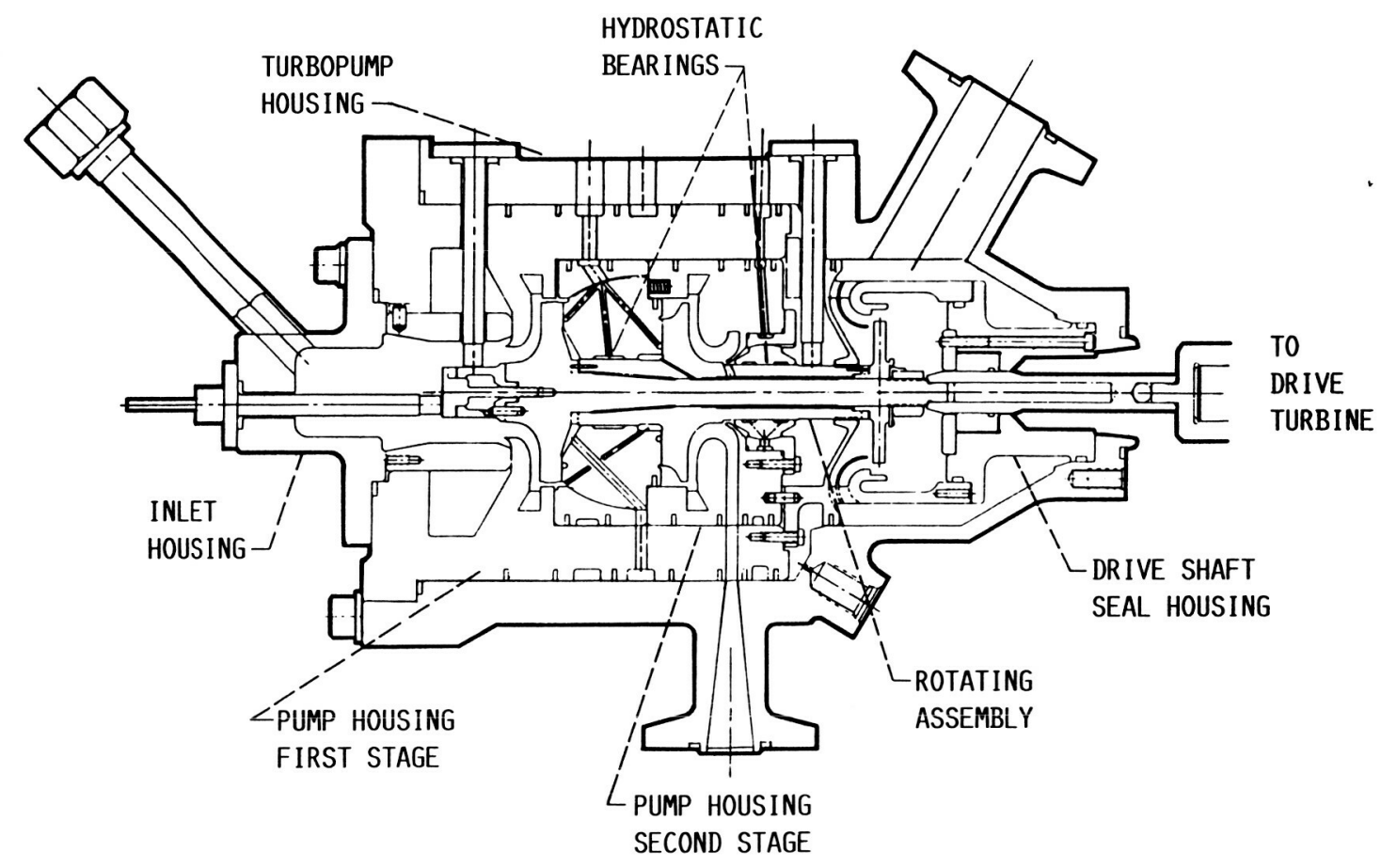

Figure 10.- HYDRostatic BEARING tester. 


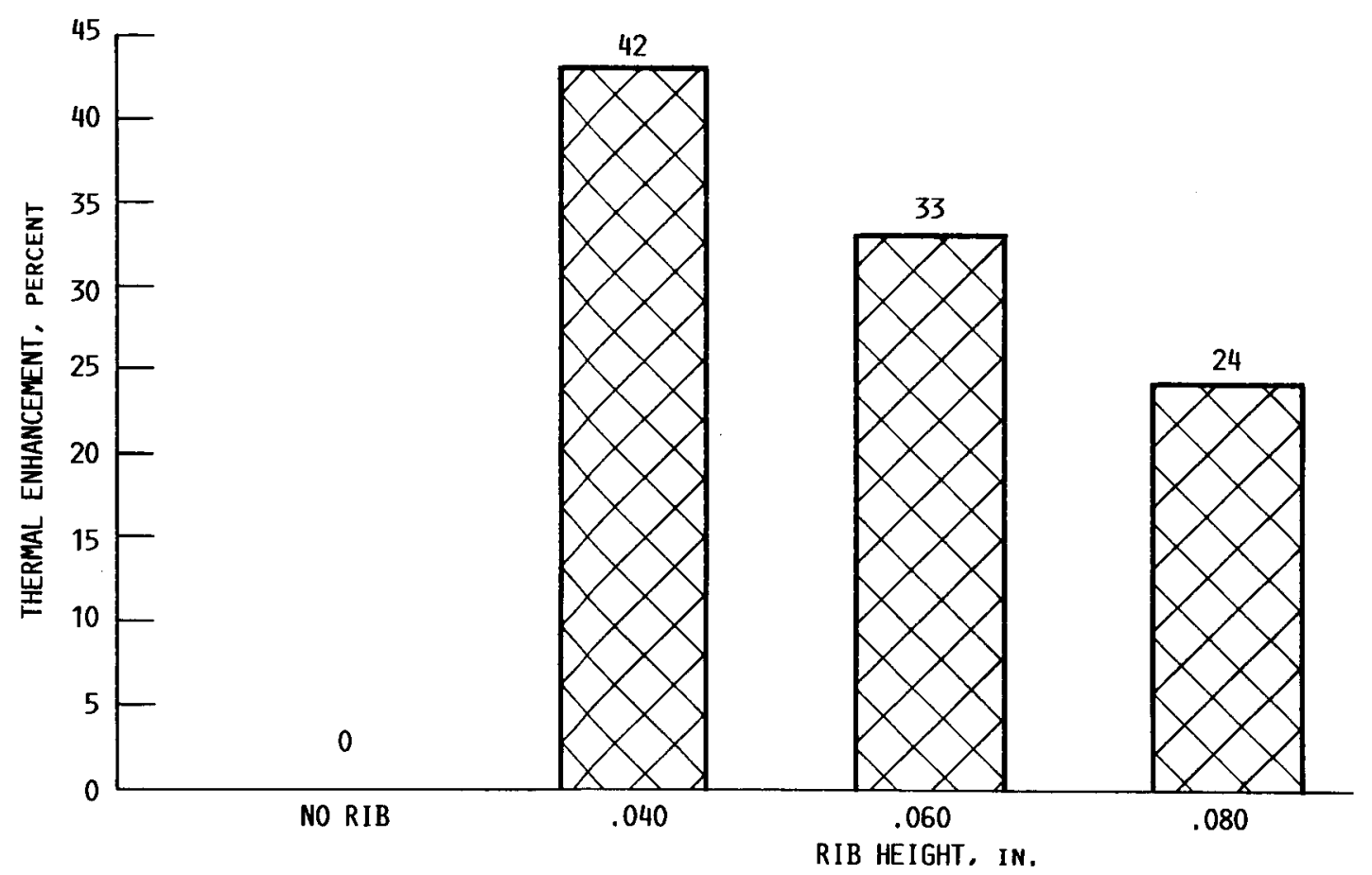

FIGURE 11.- THERMAL ENHANCEMENT FOR RIBBED COMBUSTOR HEAT TRANSFER, PROJECTED HOT FIRE CONDITIONS. 


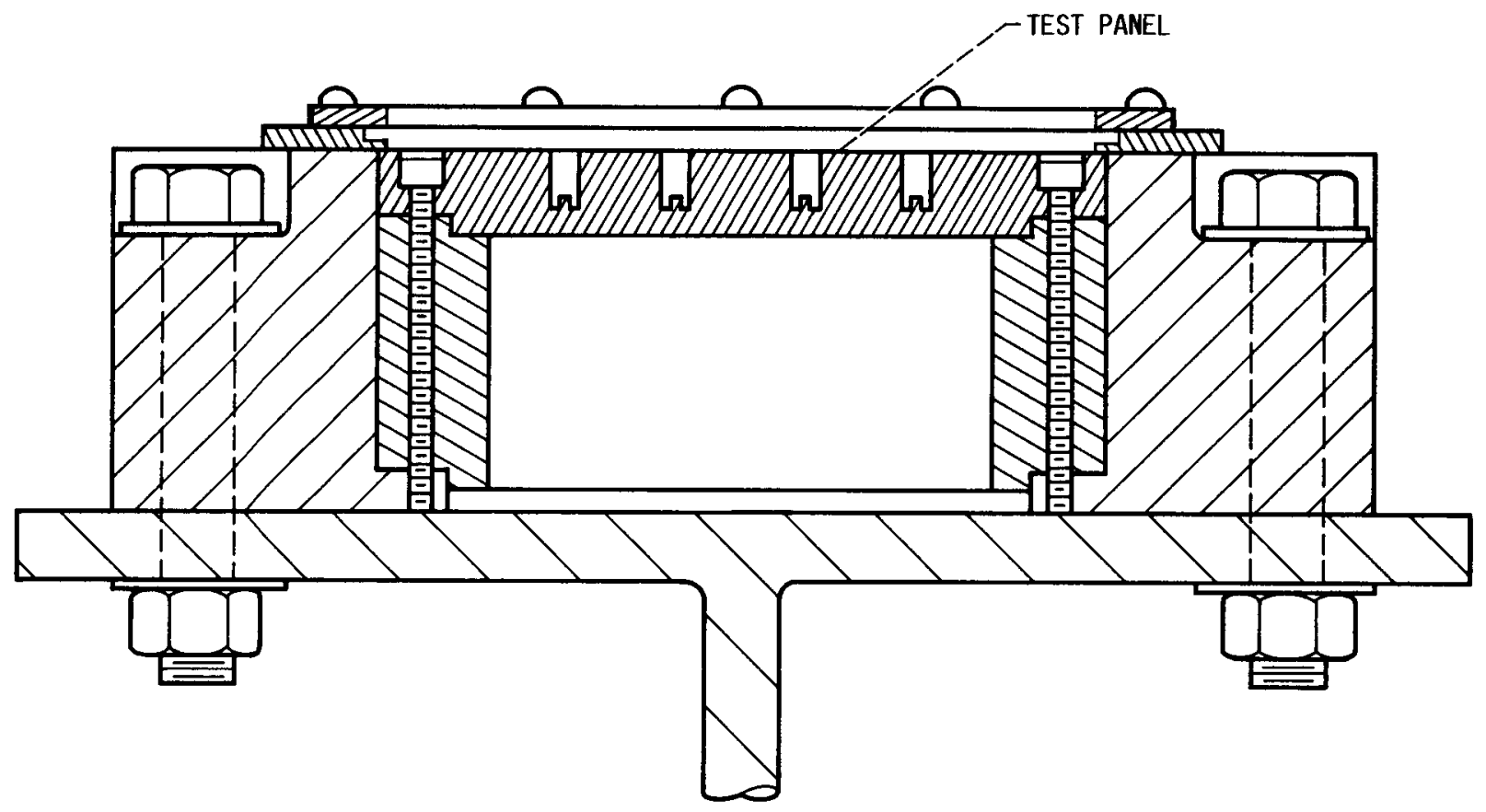

Figure 12. - COLd Flow test fixture for coolant ChanNel Passage evaluation. 


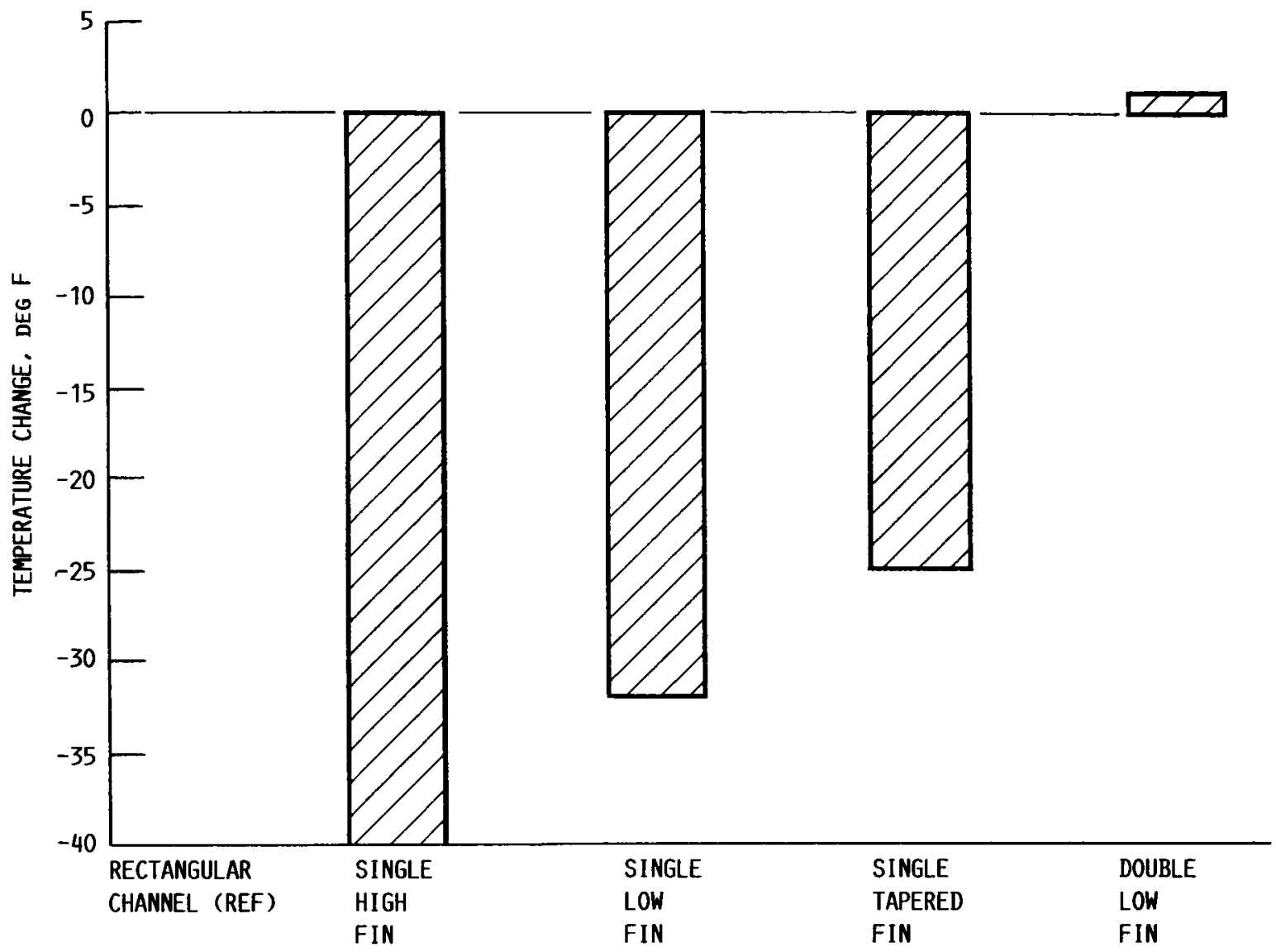

Figure 13.- COMBustor WALl temperature deCREASE for COOLANT PASSAges With Fins, PROJECTED HOT FIRE CONDITIONS. 


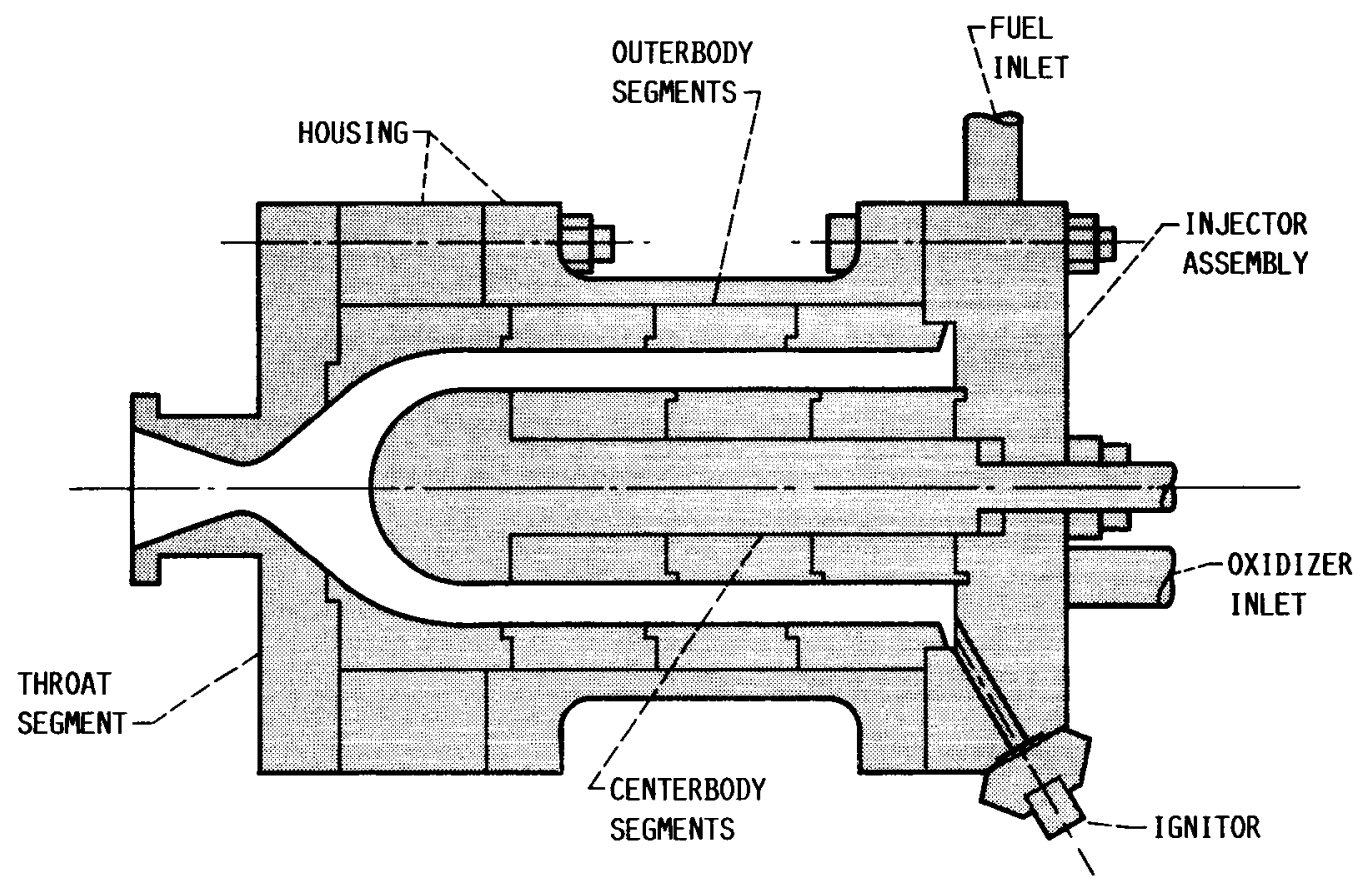

FIgURE 14.- ANNULAR HEAT SINK THRUST CHAMBER ASSEMBLY. 
ORIGINAL PACE th

OF POOn OENiTy

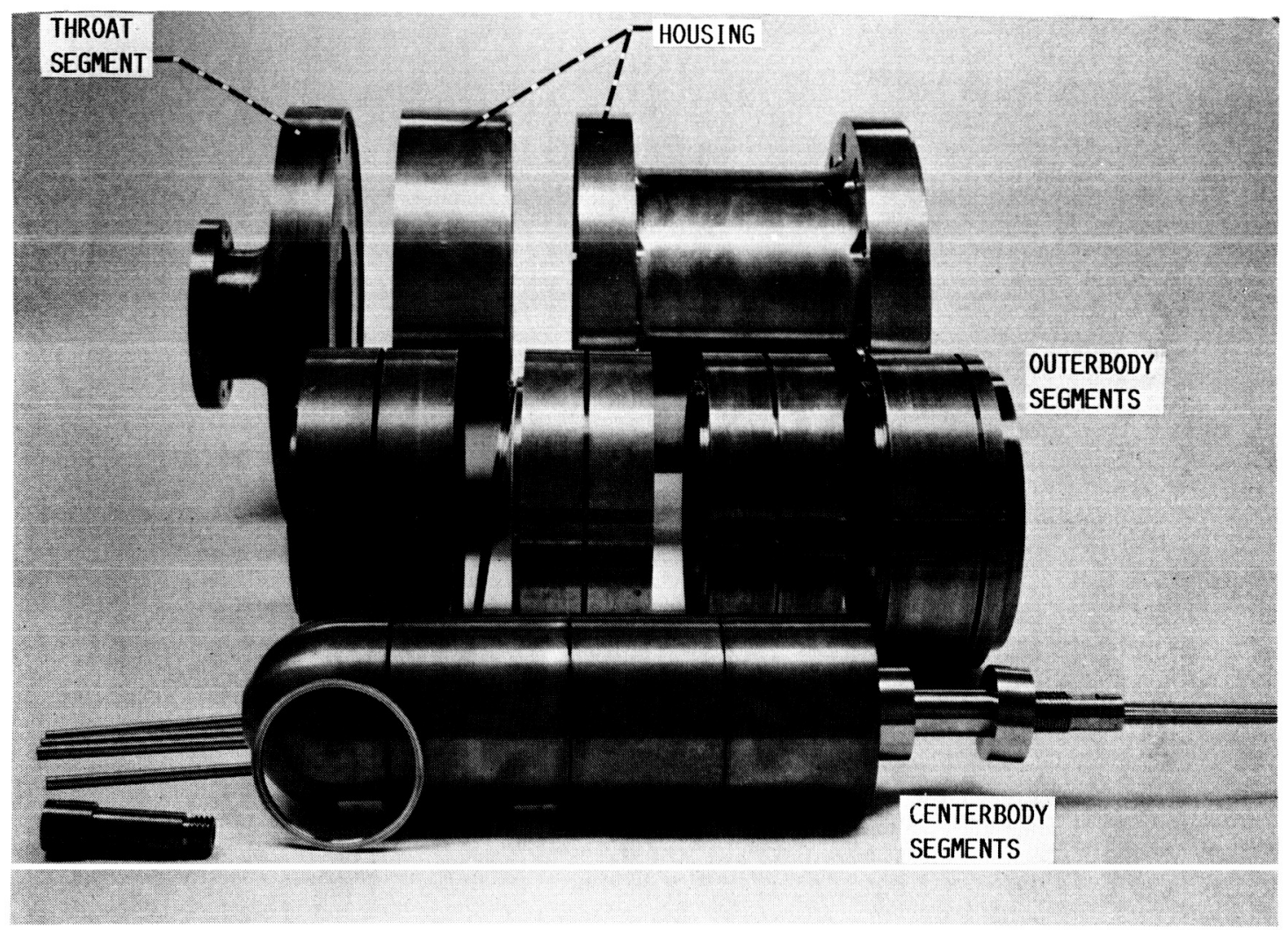

Figure 15. - ANNULAR hEAT Sink thrust CHAMBER COMPONENTS. 


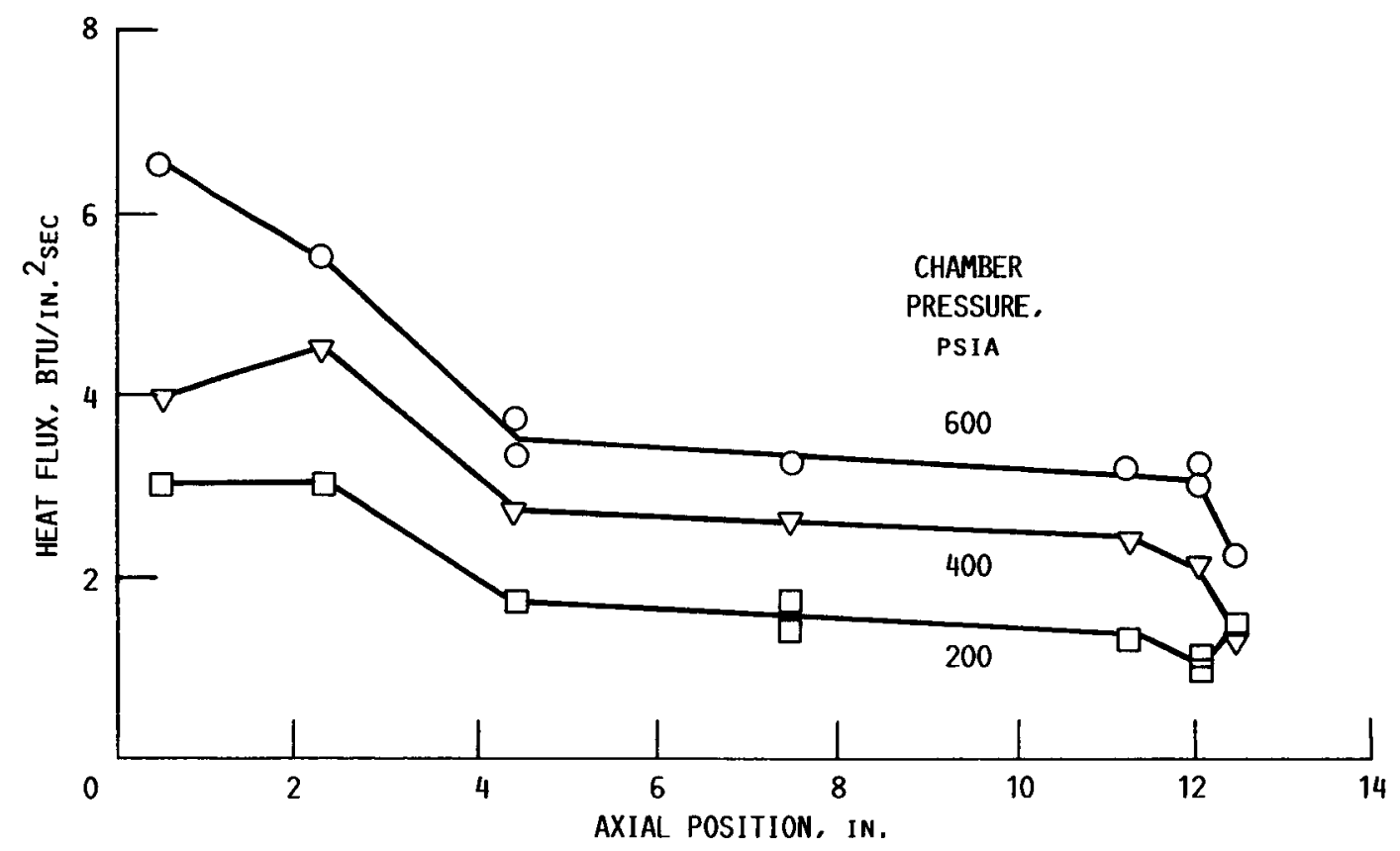

Figure 16. - Heat fluX Profile along CEnTERbody of anNUlar thrust chamber. 


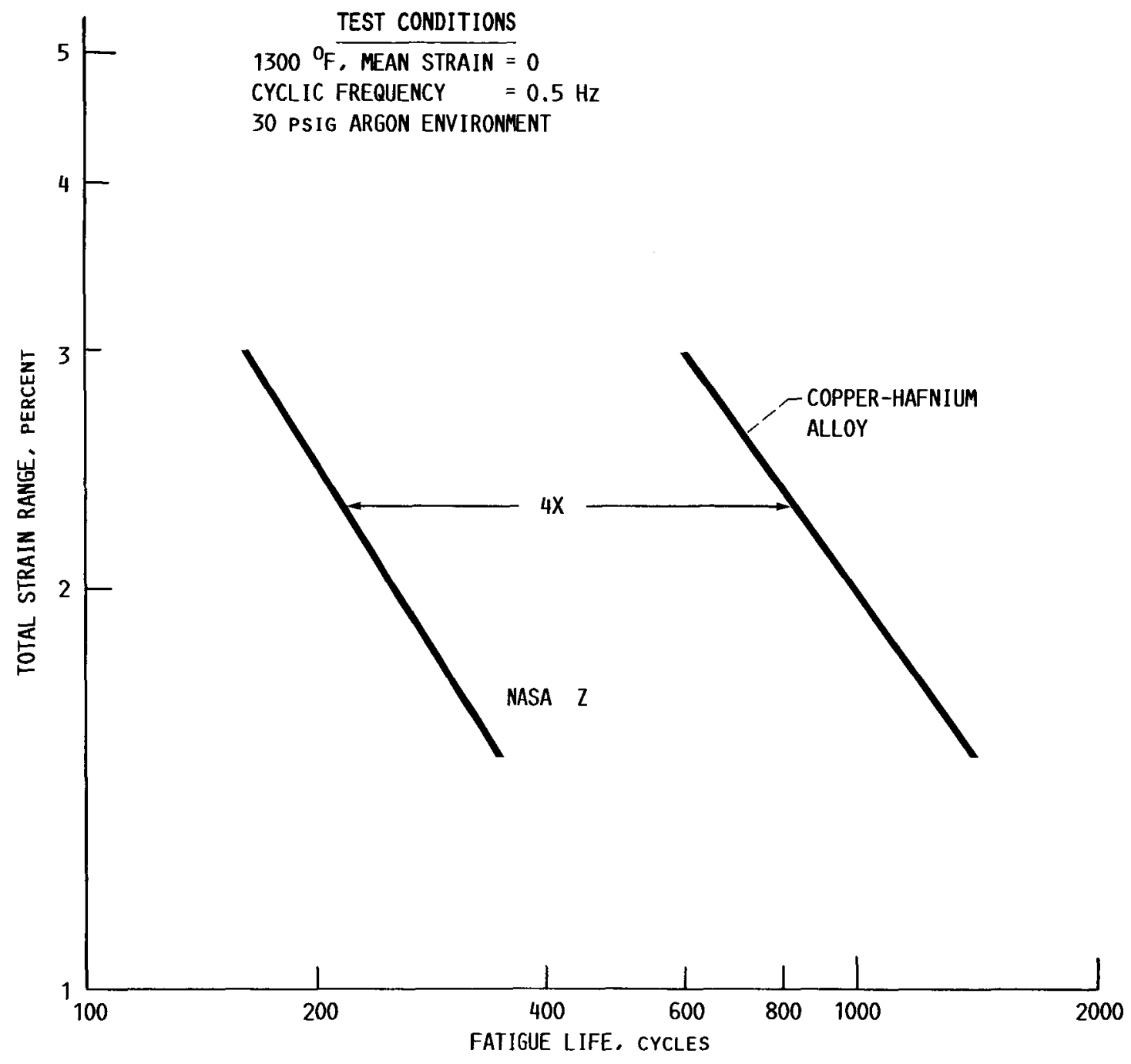

FIgURE 17.- LOW CYCLE FATIGUE OF AN ADVANCED COPPER ALLOY PRODUCED BY THE RAPID SOLIDIF ICATION RATE PROCESS. 
ORIGINAL PAGE IS

OF POOR QUALITY

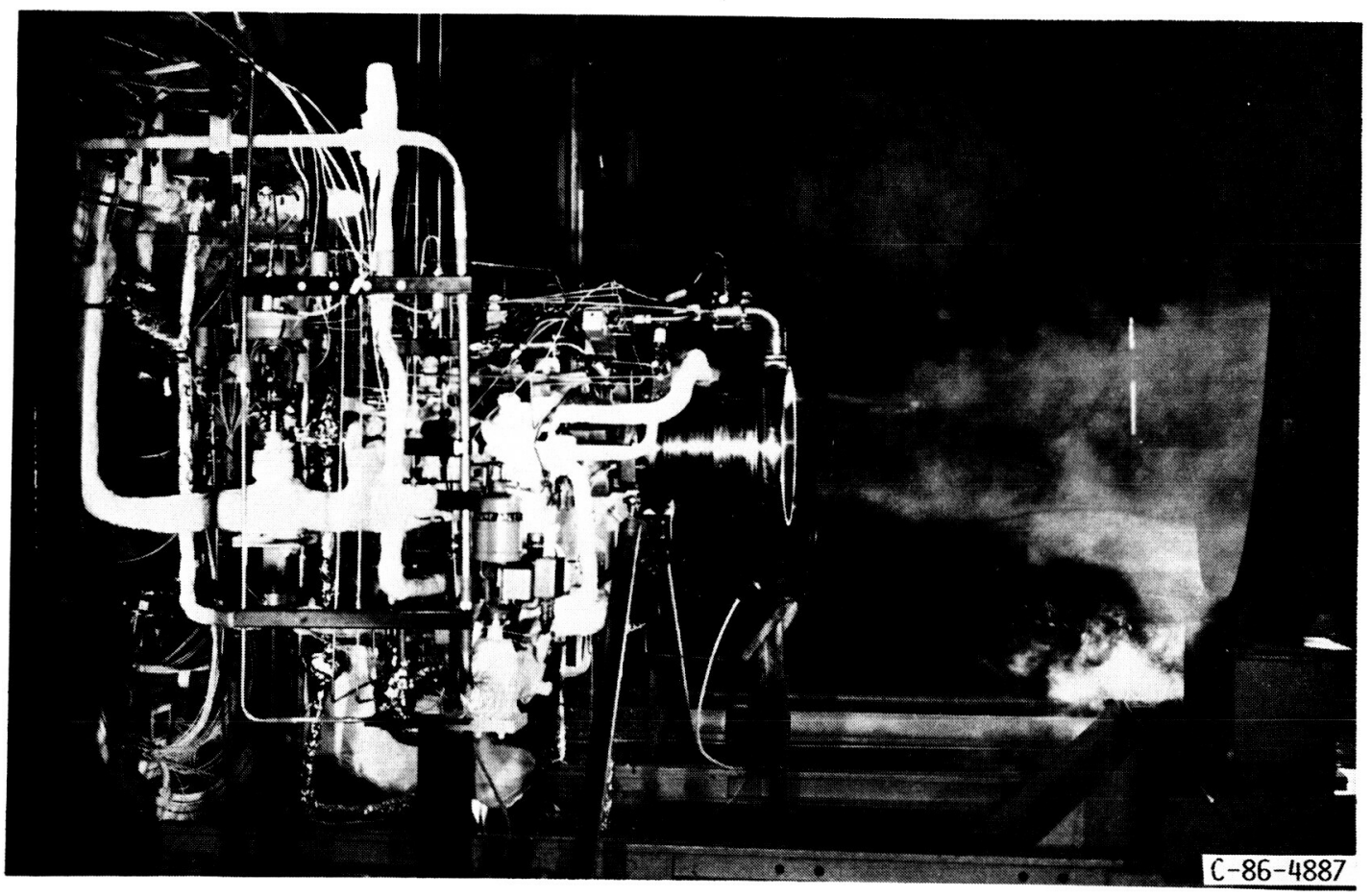

Figure 18. - TESt Firing OF the ROCKETDYNE INTEGRATED COMPONENT EVALUATOR. 
- EACH LAYER OPTIMIZED FOR ITS OWN FUNCTION

- cONTROL ISOLATED fROM hEALTH MONITOR FAILURE

- MODULAR STRUCTURE AIDS DEVELOPMENT

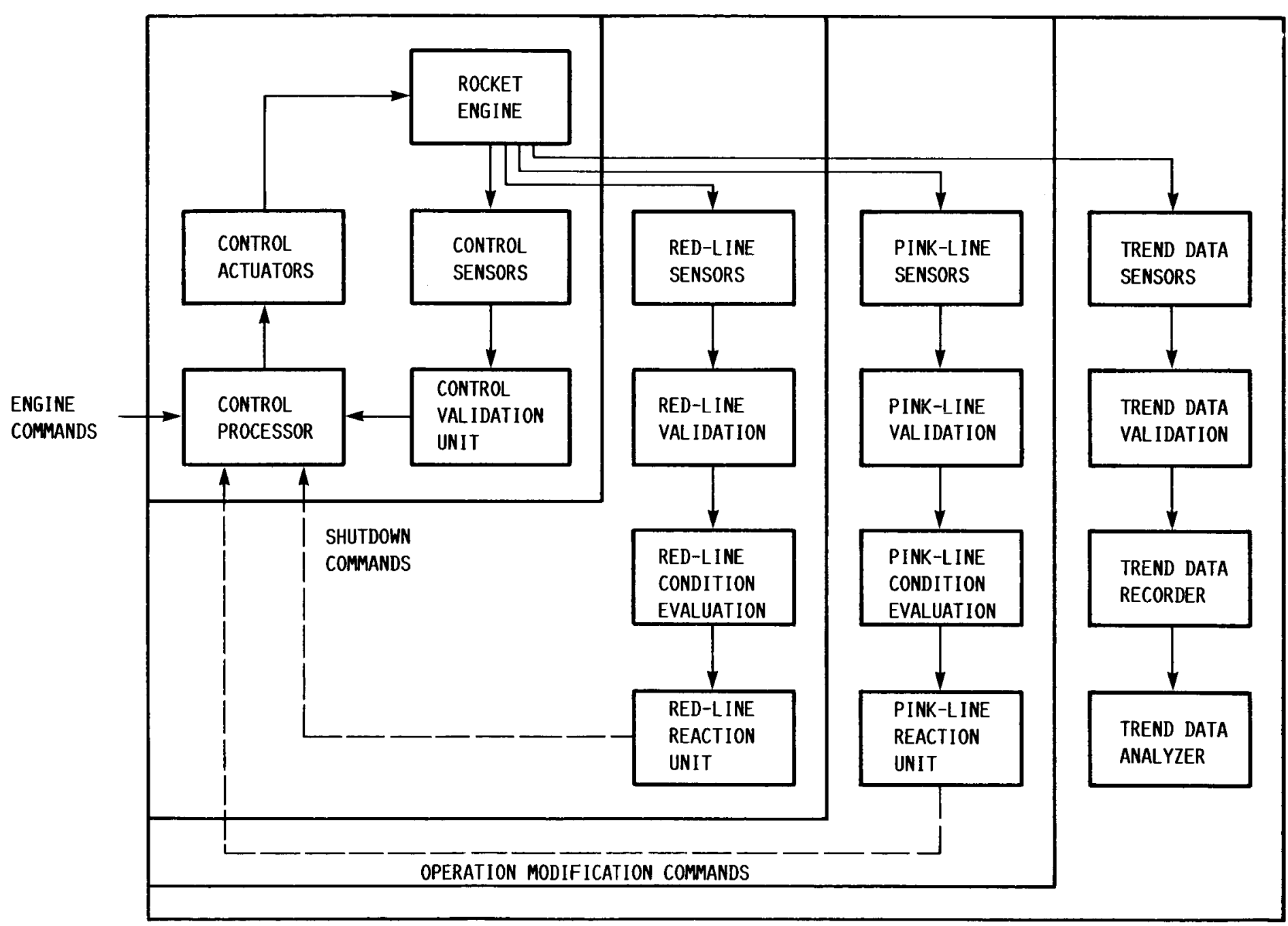

FIgURE 19, - LAYERED HEALTH MONITORING/CONTROL ARCHITECTURE. 


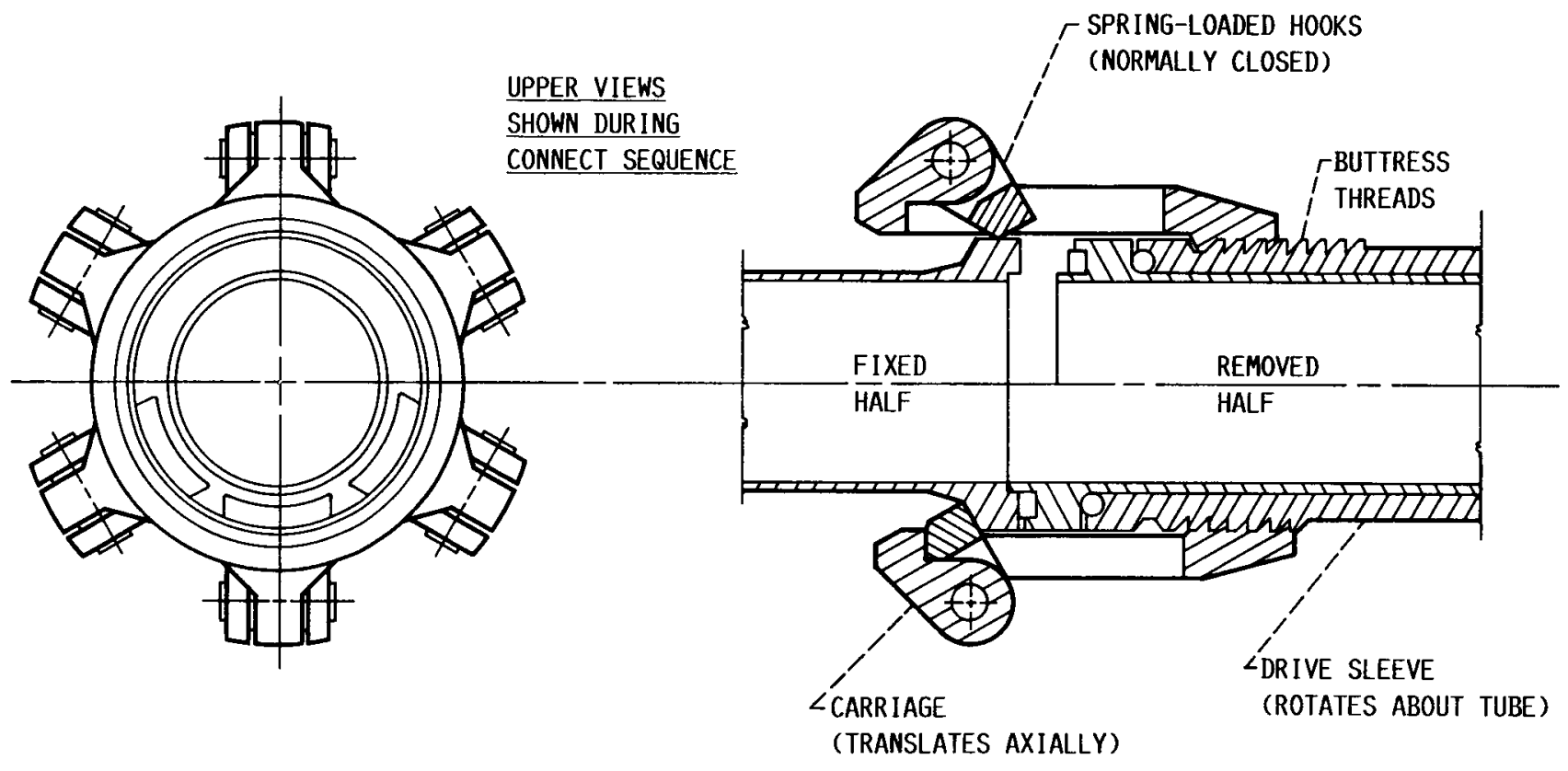

LOWER VIEWS

SHOWN ASSEMBLED

FigURE 20. - CARRIAGE-HOOK COUPLING CONCEPT FOR SPACE BASED FLUID DISCONNECTS. 


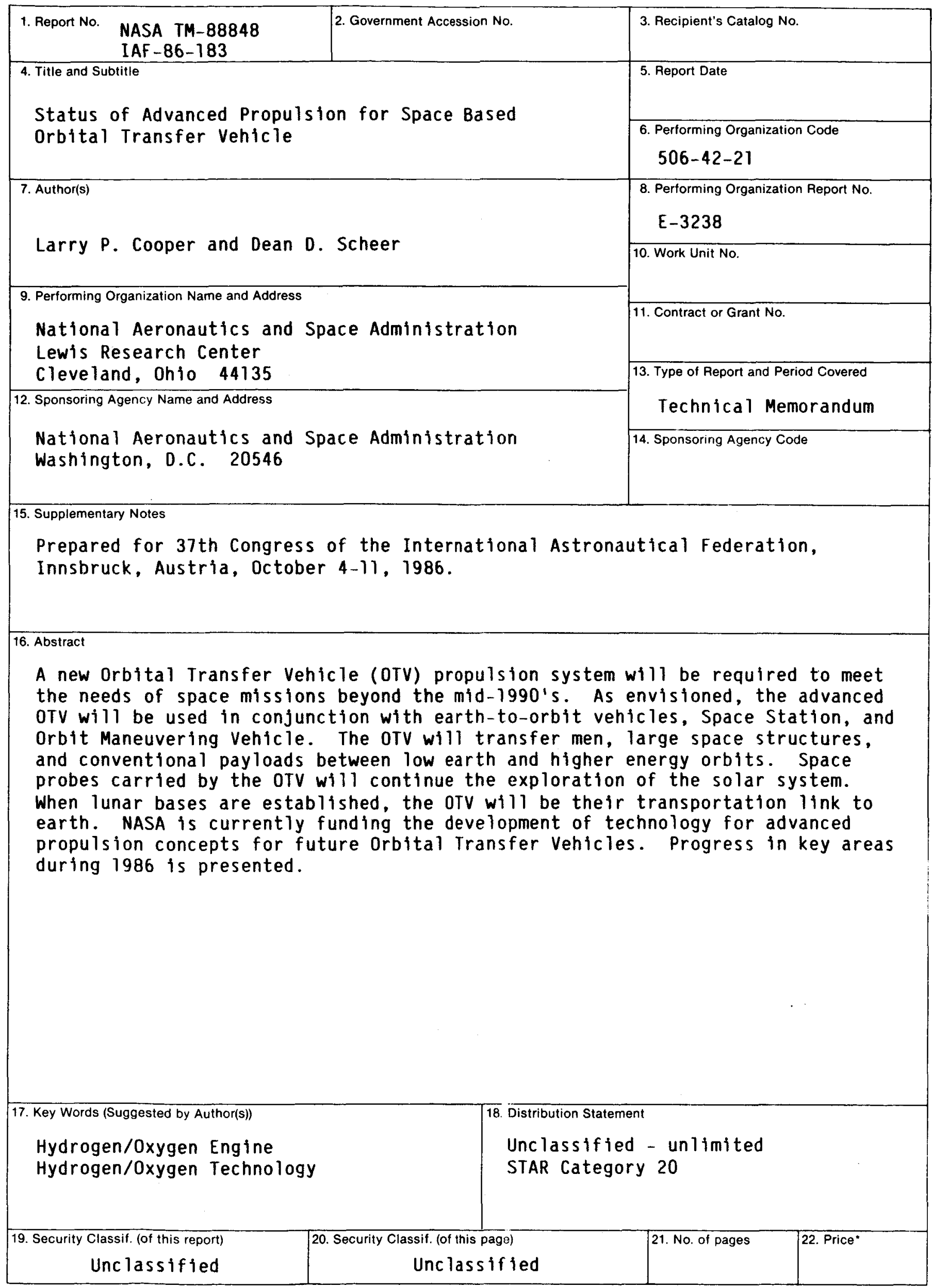

